\title{
NEW OR LITTLE-KNOWN SPECIES OF WEST INDIAN TIPULIDAE (DIPTERA) IV
}

\author{
By Charles P. Alexander *
}

The third part under the above title appeared in this Journal, vol. XXI, No. 4, October 1937. The present report is based almost entirely on extensive collections of crane-flies that were taken on various West Indian islands, chiefly by Mr. P. J. Darlington, Jr., and by Mr. Marston Bates, and are now preserved in the Museum of Comparative Zoölogy, Cambridge, Mass. The species that were taken on the higher mountains of Haiti and the Dominican Republic proved to be of especial interest and value.

In a preliminary section, I am discussing a small but very interesting collection of these flies that was taken in the island of Dominica, Lesser Antilles, by Mr. Walter H. Hodge, at the present time a student at the Gray Herbarium, Harvard University. The specimens in this latter series are preserved in my personal collection. I wish to express my sincere thanks and indebtedness to Messrs. Bates, Darlington and Hodge, and to Dr. Nathan Banks of the Museum of Comparative Zoölogy, for the privilege of studying this exceptionally interesting series of Tipulidae.

\section{Tipulidae from the Island of Dominica}

The species herewith recorded appear to be the first that have been taken in Dominica, although rather numerous species are known from St. Vincent. A most interesting general account of conditions in the island is given by Frederick A. Ober, Camps in the Caribbees (Edinburgh; David Douglas), pp. 1-366; 1880. Mr. Hodge, collector of the present material has supplied the following notes concerning the localities where the more interesting species were secured.

Morne Trois Pitons: A volcanic peak situated roughly in the center of the island and a peak which has at times been claimed to be higher than the generally accepted tallest peak, Morne Diablotin. According to Dr. Paul Griswold Howes, of Greenwich's Bruce Museum, Trois Pitons is 4,600 feet. The crane-flies were collected on one of the two lesser summits, altitude 4,500 feet, in typical winddwarfed, rain-swept cloud forest, the branches of the trees dripping

* Massachusetts State College, Amherst, Massachusetts. 
with mosses and hepatics and laden with other epiphytes, particularly water-containing Bromeliads. Here the cane-flies (Tanypremnu hodgei (sp. n.) occurred in dozens, many mating. The few I managed to pick up I had to stalk after they had alighted beneath the shelter of the leaves. During the summer months, part of the rainy season, the summits of all of Dominica's mountain peaks are almost continually enshrouded by rain clouds. Rainfall near the summits must exceed 300 inches per year.

Hatton Garden Trail: An old Carib footpath running through virgin tropical rain forest from Sylvania Estate, near Trois Pitons, to Hatton Garden Estate on the northeast (windward) coast. Craneflies were secured by sweeping the vegetation along the Layou River near its source in the neighborhood of the old abandoned Riversdale estate. Altitude approximately 2,000 feet; wainfall about 200 inches. River bed rocky and boulder-filled. Stream turbulent.

Sylvania Estate: Near the base of Trois Pitons (west). Altitude 1,800 feet; rainfall between 175 and 200 inches. Surrounding forests can be called true "rain-forests".

\section{Tanypremna (Tanypremna) hodgei sp.n.}

General coloration of mesonotum dark brown; pleura medium brown, unmarked; halters relatively short, dark brown throughout; legs brownish black, passing into black on all tarsi; wings with a strong brown suffusion, cell $S c$ and the stigma darker brown; cell 1st $M_{2}$ short and wide; abdominal tergites dull black, before midlength ringed with yellow, the outer segments and hypopygium uniformly black; male hypopygium with the dististyle at base on outer margin produced into a powerful spine.

Male.-Length about 14-15 mm.; wing 11.5-12.5 mm.; antennae $1.4 \mathrm{~mm}$.

Female.-Length about 17-19 mm.; wing 13-14 mm.; antennae $1.4 \mathrm{~mm}$.

Frontal prolongation of head very short, reddish brown; palpi black. Antennae shorter than palpi; basal segments brownish yellow, the outer ones more darkened; basal flagellar segments enlarged, the outer ones linear, with long conspicuous verticils. Head reddish fulvous, variegated with darker on vertex, expecially across the anterior vertex as a more or less continuous band.

Pronotum yellowish brown. Mesonotal praescutum chiefly covered by four dark brown, subnitidous stripes, the intermediate pair separated by a capillary darker vitta, the posterior interspaces scarcely indicated; posterior sclerites of notum dark brown, the sides of 
mediotergite a little paler. Pleura medium brown, unmarked. HaIteres short, dark brown throughout. Legs with the coxae and trochanters pale brown; femora and tibiae brownish black, the tips somewhat more blackened; all tarsi black. Wings (Fig. 1) with a strong brown suffusion, cell $S c$ and the stigma darker brown; paler streaks in centers of some of the cells, especially in female; veins brownish black. Venation: $S c_{1}$, free tip of $S c_{2}$ and $R_{1}+_{2}$ all relatively close together at wing-margin, the distance between them less than vein $R_{1}+{ }_{2}$ alone; cell 1 st $M^{2}$ short and wide, $m$-cu at near twothirds its lower face; petiole of cell $M_{1}$ variable in length, but approximately equal to $m$.

Abdomen elongated; tergites ringed with yellow and dull black, the latter including more than the outer half of the segment, as well as a very narrow darkening at base, restricting the yellow to the outer portion of basal rings; outer segments and hypopygium uniformly black; sternites more yellowish, the posterior borders of the more basal segments broadly brown, passing into black on outer segments. In the female, the yellow color is more obscured and pruinose. Male hypopygium with the outer basal portion of dististyle (Fig. 10, d) produced into a strong blackened spine; beak of style on outer margin before apex with one or two small blackened pegs. Ovipositor with valves sclerotized, relatively slender.

Habitat.-Dominica.

Holotype, ๙ิ, Morne Trois Pitons, altitude 4,500 feet, August 15,

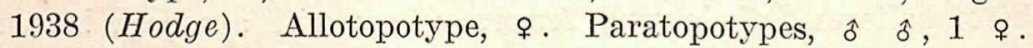

Tanypremna (Tanypremna) hodgei is named in honor of Mr. Walter H. Hodge who collected this important series of Dominican Tipulidae. It is very different from the other species of the typical subgenus that have darkened tarsi, as $I$. (I.) carbonipes Alexander (Ecuador), I. (I.) fuscitarsis Alexander (Colombia), T. (T.) kadeni Alexander (Venezuela T. (T.) invaripes Alexander (Brazil), especially in the coloration of the thoracic notum and pleura, the venation, and the structure of the male hypopygium. The genus hitherto had not been detected in any of the West Indian islands, on the mainland extending from southwestern Mexico southward to southeastern Brazil.

Limonia (Limonia) apicata dominicensis subsp. $\mathrm{n}$.

Male.-Length about $5 \mathrm{~mm}$; wing $5.5 \mathrm{~mm}$.

Female.-Length about $7.5 \mathrm{~mm}$; wing $7 \mathrm{~mm}$.

Characters as in typical apicata Alexander (ranging from northern Florida, subspecies subapicata Alexander, to Peru, subspecies na- 
poensis Alexander), differing only in slight hypopygial characters. Male hypopygium with the gonapophyses (Fig. 13) very broadly expanded and compressed, before apex bearing a small spinous point.

Habitat.-Dominica.

Holotype, o, Layou River, on Hatton Garden Trail, altitude 2,000 feet, August 16, 1938 (Hodge). Allotype, ․ Sylvania Estate, altitude 1,800 feet, August 29, 1938 (Hodge).

Limonia (Rhipidia) domestica (Osten Sacken).

Dominica: Marigot, July 1938 (Hodge). Lisdara Estate, altitude 1,800 feet, August 1937 (Hodge).

\section{Limonia (Rhipidia) costalis (Williston).}

Dominica: Sylvania Estate, altitude 1,800 feet, August 29, 1938 (Hodge).

\section{Limonia (Geranomyia) cinereinota (Alexander).}

Dominica: Layou River, on Hatton Garden Trail, altitude 2,000 feet, August 16, 1938 (Hodge). Hitherto from Greater Antilles; northern South America, south to Paraguay.

\section{Limonia (Geranomyia) dominicana sp. n.}

Mesonotal praescutum pale gray, with a broad, yellowish brown, median stripe, the lateral borders of the sclerite broadly dark brown; knobs of halteres dark brown; femora yellow, with a narrow brown subterminal ring; wings yellow, variegated with pale brown, the dark areas at origin of $R s$ and fork of $S c$ barely connected; $S c$ short, $S c_{1}$ ending about opposite one-fourth the length of $R s$; abdominal segments yellow, narrowly ringed caudally with brown; male hypopygium with the rostral prolongation of ventral dististyle short, with a powerful common tubercle bearing two unusually long curved spines; aedeagus at apex with two conspicuous lobes.

Male.-Length, excluding rostrum, about $7 \mathrm{~mm}$; wing $6.8 \mathrm{~mm}$; rostrum about $3 \mathrm{~mm}$.

Rostrum and palpi black, the former elongate. Antennae with scape and pedicel black, flagellum pale brown; flagellar segments oval. Head dark gray, the anterior vertex and a central line back to occiput light gray.

Mesonotal praescutum pale gray, with a broad yellowish brown median stripe that is a little darker in front, on posterior half narrowly delimited by delicate dark margins; lateral praescutal borders broadly and conspicuously dark brown; scutellum and median region 
of scutum pale testaceous, the scutal lobes darker, delimited internally by a narrow dark line; postnotum pale. Pleura yellow, variegated with brown, especially on dorsal portion. Halteres with stem pale yellow, knob dark brown. Legs with the coxae yellow, fore pair a trifle darker; trochanters yellow; femora obscure yellow, with a narrow, dark brown, subterminal ring, about equal in extent to the clear yellow apex; remainder of legs obscure yellow, the terminal tarsal segments a little darker. Wings yellow, the costal border more saturated; a conspicuous pale brown pattern, as follows: A series of five costal darkenings, the first at arculus, second at supernumerary crossvein in cell $S c$, both small; third area larger; at origin of $R s$ and fork of Sc, barely interconnected and forming an irregular area; stigma relatively small; fifth darkening small, at end of vein $R_{3}$; cord and outer end of cell $1 s t M_{2}$ seamed with brown; small marginal dark clouds at ends of veins $M_{3}$ and $M_{4}$, with larger and more conspicuous ones on veins $C u, 1 s t A$ and $2 n d A$; veins yellow, slightly darker in the clouded areas. Venation: $S c$ relatively short, $S c_{1}$ ending about opposite one-fourth the length of $R s, S c_{2}$ at its tip; cell 1st $M_{2}$ about as long as vein $M_{1}+{ }_{2}$ beyond it; $m$-cu at fork of $M$.

Abdominal segments yellow, narrowly ringed caudally with brown; hypopygium yellow brown. Male hypopygium with the caudal margin of tergite nearly truncate or very feebly emarginate. Ventral dististyle much more extensive than basistyle; rostral prolongation short and stout, more than one-half of its outer margin involved in a large tubercle that bears the two long spines; these latter borne at tip of tubercle, subequal in length, strongly curved, exceeding in length the dorsal dististyle; base of tubercle expanded proximad into a flange; apex of rostrum beyond tubercle very short, only about one-third the length of tubercle. Gonapophyses with mesalapical lobe blackened, expanded, at apex narrowed into a very short decurved beak. Aedeagus short, at apex with two conspicuous lobes.

Habitat.-Dominica.

Holotype, ô, Sylvania Estate, altitude 1,800 feet, August 30, 1938 (Hodge).

The most similar described species include Limonia (Geranomyia) carunculata Alexander and $L$. (G.) deliciosa Alexander, both of which are readily distinguished by the structure of the male hy. popygium.

Limonia (Geranomyia) microphaea sp. n.

Size very small (wing, $\hat{o}$, less than $5 \mathrm{~mm}$.); general coloration brownish black, unmarked; rostrum elongate, about two-thirds the 
length of body; halteres brownish black, the base of stem obscure yellow; wings strongly tinged with brown, stigma darker brown; $S c$ relatively short, $S c_{1}$ ending about opposite one-forth to one-fifth the length of $R s$; cell 2nd $A$ narrow, especially on outer half; abdominal tergites brownish black, basal sternites obscure yellow; hypopygium uniformly blackened; male hypopygium with the ventral dististyle much more extensive than the basistyle; rostral prolongation long and slender, at base with a low common tubercle from the summit of which arise two straight spines of moderate length, these spines shorter than the prolongation; gonapophyses with mesal-apical lobe a short curved black spine.

Male.-Length, excluding rostrum, about $4 \mathrm{~mm}$; wing $4.8 \mathrm{~mm}$; rostrum about $2.8 \mathrm{~mm}$.

Rostrum very long, about two-thirds the length of body, black, the distal third of paraglossae paling to brown. Antennae broken. Head dark.

Mesonotum almost uniformly dark brown to brownish black, the surface polished, the humeral region of praescutum a little brightened. Pleura dark brown, the ventral portion of sternopleurite paler. Halteres brownish black, the base of stem obscure yellow. Legs with coxae brownish yellow; trochanters yellow; remainder of legs broken. Wings strongly tinged with brown, cells $C$ and $S C$ a trifle darker; stigma oval, darker brown; veins dark brown. Venation: $S c$ relatively short, $S c_{1}$ ending about opposite one-fourth to onefifth of $R s, ' S c_{2}$ at its tip; $R s$ relatively long, fully three times the arcuated basal section of $R_{4}+_{5}$; cell 1st $M_{2}$ nearly as long as vein $M_{1}{ }^{+}{ }_{2}$ beyond it; $m$-cu shortly before fork of $M$; cell $2 n d A$ narrow, especially on outer half.

Abdominal tergites brownish black; basal sternites obscure yellow; hypopygium uniformly blackened. Male hypopygium (Fig. 15) with the caudal margin of tergite with a broad U-shaped notch, the lateral lobes broad. Dorsal dististyle only gently eurved, the tip a slender spine. Ventral dististyle large and fleshy, much more extensive than basistyle; rostral prolongation long and slender, at base on outer face with a low common tubercle, from summit of which arise two relatively short, straight spines, these shorter than the prolongation distad of tubercle. Gonapopyses with mesal-apical lobe a short curved black spine, the tip acute.

Habitat.-Dominica.

Holotype, ŝ, Layou River, on Hatton Garden, altitude 2,000 feet, August 16, 1938 (Hodge). 
Limonia (Geranomyia) microphaea is somewhat similar to $L$. (G.) cerberus Alexander and $L$. (G.) fluxa Alexander, differing especially in the small size, uniformly dark brown mesonotum, and structure of the male hypopygium.

Limonia (Geranomyia) plumbeipleura Alexander.

Dominica: Sylvania Estate, altitude 1,800 feet, August 28-30, 1938 (Hodge). Formerly known from northern South America and Trinidad.

\section{Limonia (Geranomyia) sylvania sp. n.}

Allied to plumbeipleura; size small (wing, $\hat{\delta}$, under $6 \mathrm{~mm}$.); mesonotum buffy brown, with three brown praescutal stripes; femora obscure yellow, with a narrow brown subterminal ring; wings yellow, patterned with brown, the dark area at origin of $R s$ also involving the fork of Sc; abdominal segments dimidiate, the bases darkened, the apices yellow; male hypopygium with the spines of the rostral prolongation of ventral dististyle arising from tubercles that are much shorter than the spines themselves; mesal-apical lobe of gonapophysis a short blackened horn.

Male--Length, excluding rostrum, about $4.6-5 \mathrm{~mm}$; wing 5.4 . $5.8 \mathrm{~mm}$.; rostrum about $2 \mathrm{~mm}$.

Rostrum black, relatively short. Antennae black throughout. Head black, the median region of vertex lined with light gray.

Mesonotum obscure buffy brown, with three distinct but somewhat poorly delimited brown stripes; scutum buffy brown, the lobes variegated with darker brown; posterior sclerites of notum chiefly darkened. Pleura with propleura obscure yellow; dorsal mesopleura and pleurotergite weakly darkened, the sternopleurite and meron yellow. Halteres obscure yellow, the base of stem a little brighter. Legs with the coxae and trochanters yellow; femora obscure yellow, with a narrow brown subterminal ring, the yellow apex beyond slightly wider; in cases, the femora are darker, more brownish yellow, and the subterminal dark ring is preceded by a narrow, clearer yellow annulus; tibiae and tarsi yellow, the outer tarsal segments darkened. Wings yellow, more saturated in the costal and prearcular fields, the apex, in cases, weakly darkened; a sparse brown pattern, including four subcostal areas that are more restricted than the interspaces; first area above arculus, tending to become evanescent; second area at supernumerary crossvein in cell $S c$; third area large, irregular in outline, common to the origin of $R s$ and fork of $S c$; fourth area largest, at stigma; narrower brown seams along cord, outer end of 
cell 1 st $M_{2}$ and on distal portion of vein 2nd $A$; veins yellow, darker in the infuscated areas. Venation: $S c$ relatively short, $S c_{1}$ ending a short distance beyond origin of $R s$, at about opposite one-fifth the length of this vein; $m$-cu at fork of $M$.

Abdomen more or less dimidiate, the bases of the segments narrowly darkened, the apices more extensively yellow; subterminal segments uniformly darkened; hypopygium yellow. Male hypopygium (Fig. 16) with the caudal margin of tergite broadly and conspicuously emarginate, the margins of the lobes broadly thickened and sclerotized; tergal setae coarser and more sparse than in plumbeipleura. Dorsal dististyle a curved sickle. Ventral dististyle large and fleshy, the rostral prolongation and spines much as in plumbeipleura; rostrum nearly parallel-sided, scarcely expanded outwardly; spines equal in size, the tubercle of the loyer or more cephalic spine shorter, less than half the spine; both tubercles much shorter than the spines they bear, the outer being about two-thirds its spine. Gonapophyses with mesal-apical lobe appearing as a short blackened horn.

Habitat.-Dominica.

Holotype, ô, Sylvania Estate, altitude 1,800 feet, August 28, 1938 (Hodge): Paratopotype, ô.

Although allied to Limonia (Geranomyia) plumbeipleura Alexander (Dominica and Trinidad; northern South America) and to L. (G.) marthae Alexander (Mt. Santa Marta, Colombia), the present fly is distinct in the characters listed in the diagnosis. The size and the general structure of the male hypopygium is more as in marthae but the coloration of the legs and details of the hypopygium in the latter, especially the very large ventral dististyle and its rostral spines, indicate a distinct species. All three forms constitute a group of closely interrelated flies.

\section{Limonia (Geranomyia) tibialis (Loew).}

Dominica: Sylvania Estate, altitude 1,800 feet, August 30, 1938 (Hodge).

Polymera (Polymera) albitarsis dominicae subsp. $\mathrm{n}$.

Male.-Length about $4.5 \mathrm{~mm}$; wing $5.2 \mathrm{~mm}$; antennae about $6 \mathrm{~mm}$.

Differs from typical albitaris Williston (St. Vincent), as follows:

Size small. Mesonotum uniformly dark brown, only the humeral region and pretergites restrictedly obscure yellow. Pleura chiefly 
covered by a very broad, black stripe, only the stenopleurite and ventral meron abruptly yellow. Legs with fore coxae blackened on basal two-thirds, the apex and remaining coxae light yellow; femora brown, passing into dark brown, the tips abruptly whitened; tibiae dark brown; outer tarsal segments whitened, in degree less than in typical albitarsis, the proximal half of the second tarsal segment of posterior leg darkened; in albitarsis, on the posterior legs, only the basitarsi are darkened. Wings very strongly suffused with brown; veins darker. Venation: $S c$ short, $S c_{1}$ ending opposite fork of the short $R s ; R_{2}+{ }_{3}+_{4}$ long, nearly straight, fully as long as $R s$ and nearly twice $R_{2}+_{3} ; R_{1}+_{2}$ and $R_{2}+_{3}$ subequal.

Habitat.-Dominica.

Holotype, ô, Sylvania Estate, altitude 1,800 feet, August 30, 1938 (Hodge).

\section{Rhabdomastix fumipennis sp. n.}

General coloration brownish black, the thorax unpatterned; antennae black; halteres and legs brownish black; wings with a strong brown suffusion; stigma ill-defined, very slightly darker than the ground; $R s$ approximately twice $R_{2}+_{3}+_{4}$; abdomen black.

Female.-Length about 5.5-6.5 mm.; wing 4.5-5 mm.

Rostrum and palpi brownish black. Antennae black throughout, of moderate length (female), if bent backward scarcely attaining the wing-root; flagellar segments subcylindrical. Head blackish.

Thorax uniformly brownish black, without markings. Halteres brownish black, the extreme base of stem pale. Legs with the coxae brownish black; trochanters testaceous; remainder of legs brownish black, the subterminal tarsal segments a little paler. Wings (Fig. 9) broad, with a strong brown suffusion; stigma ill-defined, very slightly darker brown than the ground; veins brown. Wing-veins chiefly naked; a series of trichia on outer ends of veins $R_{5}, M_{1}+_{2}$ and $M_{3}$; in cases, a single or very sparse trichia on $M_{4}$ and distal section of $C u_{1}$. Venation: $R s$ considerably longer than in parvula, a little more than twice $R_{2}+_{3}+_{4} ; R_{4}$ slihtly variable in length, subequal to or shorter than $R_{2}+{ }_{3}+{ }_{4}$.

Abdomen black. Valves of ovipositor, especially the cerci, elongate and very slender.

Habitat.-Dominica.

Holotype, î, Sylvania Estate, altitude 1,800 feet, August 29, 1938 (Hodge). Paratopotypes, 7 우 9. 
Rhabdomastix fumipennis seems undoubtedly to be closed to $R$. parvula Alexander (parva Alexander, preoccupied), which belongs to the subgenus Sacandaga Alexander. In the absence of the male sex of the present fly, it seems inadvisable to refer it to a given subgenus since the antennae are short in the females in both of the regional subgenera; the males of Rhabdomastix Skuse, s. s., have the antennae much longer than the body, of Sacandaga, short as in the females. From parvula, the present fly differs most evidently in the broad wings with the venational details distinct, notably the long $R s$.

\section{Erioptera (Mesocyphona) caloptera Say}

Dominica: Sylvania Estate, altitude 1,800 feet, August 29, 1938 (Hodge).

\section{Toxorhina (Toxorhina) fumipennis sp. n.}

General coloration of mesonotum dark brown, the lateral borders of praescutum broadly buffy gray; halteres and legs dark brown; wings with a strong brown suffusion, the veins darker; veins $M_{3}+_{4}$ and $M_{4}$ subequal; $m$-cu about one-third its length before fork of $M$.

Female.-Length, excluding rostrum, about $7 \mathrm{~mm}$; wing $5.2 \mathrm{~mm}$.

Rostrum black, its apex broken. Head dark gray.

Cervical region and pronotum blackened. Mesonotal praescutum with disk brown, the lateral margins broadly buffy gray; posterior sclerites of notum dark, sparsely pruinose. Pleura with central portion chiefly infuscated, paler dorsally and ventrally. Halteres dark brown. Legs dark brown. Wing's with a strong brown suffusion, unpatterned; veins "darker than the ground. Venation: $S c_{1}$ ending opposite origin of $R s, S c_{2}$ near its tip; basal section of $M_{1}+_{2}$ about two-thirds the second; $M_{3}+_{4}$ subequal to $M_{4}$ alone; $m$-cu about one-third its length before fork of $M$.

Abdominal tergites brownish black, sparsely pruinose; sternites paler.

Habitat.-Dominica. 1938 (Hodge).

$\therefore$ ¿̇ype, ô, Sylvania Estate, altitude 1,800 feet, August 2:,

The strongly infumed wings of the present species readily distinguish it from all other members of the genus so far described in the Neotropical fauna. 


\section{Tipulidae from the Greater Antillean Islands. Descriptions of new species and records of distribution from Cuba, Hispaniola, Jamaica and Puerto Rico.}

\section{Tipula darlingtoniana sp. n.}

Size large (wing, $\hat{o}$, over $25 \mathrm{~mm}$.) ; mesonotum buffy, with four entire brown stripes, the interspaces with brown setigerous punctures; antennae yellow; legs with femora obscure brownish yellow, the tips blackened; wings whitish subhyaline, patterned with various shades of brown; $R s$ long, about three times $m$-cu; abdominal tergites buffy, quadrivittate with brown; cerci long, slender, straight.

Female.-Length about $31 \mathrm{~mm}$; wing $26 \mathrm{~mm}$.

Frontal prolongation of head brownish gray above, brown on sides and beneath; nasus long and slender; palpi black, the apices of the intermediate segments narrowly yellow. Antennae yellow; first flagellar segment longer than the scape; verticils of intermediate segments exceeding the segments in length. Head grayish brown, with a narrow, dark brown, median vitta on posterior vertex; vertical tubercle relatively low.

Pronotum buffy, with three brown areas, the interspaces with brown setigerous punctures. Mesonotal praescutum buffy, with four entire dark brown stripes, the intermediate pair contiguous or narrowly confluent at ends, the median portion a little infuscated and lined centrally with darker, humera region of praescutum extensively dark brown; interspaces with conspicuous brown setigerous punctures; seutal lobes brownish gray, narrowly darker brown on mesal edge; median region of praescutum gray, with a capillary darker vitta; scutellum whitish gray, with a median brown vitta, parascutella dark; mediotergite gray, the central fourth whitish gray, bordered sublaterally by dark brown. Pleura brownish gray, clearer gray on ventral sclerites, sparsely variegated with brown on dorsal anepisternum and sternopleurite, and, especially, on the pleurotergite. Halteres with stem yellow, knob infuscated. Legs with the coxae gray, with brown punctures; trochanters obscure yellow; femora obscure brownish yellow, the tips rather narrowly blackened; tibiae obscure yellow, the tips passing into black; first and second tarsal segments obscure yellow, the tips darkened; remainder of tarsi black. Wings whitish subhyaline, conspicuously patterned with various shades of brown; prearcular field chiefly darkened, its outer end white; cell $C$ uniformly brown except at outer end; cell $S c$ brownish yellow, with four major areas that extend into cell $R$, these 
pale brown, bordered posteriorly by darker brown; outer radial field pale brown, bordered behind by a dark brown seam on outer two-thirds of vein $R_{4}+{ }_{5}$; basal two-thirds and outer end of cell $M$ brown, the latter area paler, the cubital veins narrowly bordered by dark brown; outer portions of Anal cells pale brown; cell $C u$ and basal third of cell 1st A washed with darker brown; restricted darker brown seams at outer end of cell 1 st $M_{1}+_{2}, m$-cu and veins at base of cell 1 st $M_{2}$, and on vein $2 n d A$; veins brown, a little paler in the ground areas. Venation: Distal half of vein $R_{1}+_{2}$ pale but preserved; $R s$ very long, about three times as long as $m$-cu; petiole of cell $M_{1}$ longer than $m$; basal section $M_{4}$ erect, exceeding $M_{3}+_{4}$.

Abdominal tergites with the ground color buffy, variegated by two submedian dark stripes that are separated by a capillary median ground vitta; additional sublateral brown stripes, the interspaces with brown setigerous punctures; sternites chiefly dark brown, variegated by buffy. Ovipositor with long slender straight cerci; hypovalvae stouter.

Habitat.-Dominican Republic.

Holotype, s, Valle Nuevo, southeast of Constanza, altitude about 7,000 feet, August 1938 (Darlington).

I take very great pleasure in naming this striking and distinct fly in honor of the collector, Dr. P. J. Darlington, Jr., who has added so materially to our knowledge of the Tipulidae of Hispaniola. The species appears to belong to the glaphyroptera group of the genus, including a vast aggregation of South and Middle American forms, but not previously known from the West Indian islands. It is amply distinct from all other known species, especially in the coloration of the antennae, mesonotum, legs and wings.

\section{Tipula (Yamatotipula) ludoviciana Alexander.}

Cuba: Santiago de las Vegas, March 31, 1931 (A. Otero); April 20, 1931 (A. Cremata).

\section{Nephrotoma circumscripta (Loew).}

Cuba: Pico Turquino, Oriente altitude 5,000 feet, June 1936 (Julián Acuna).

\section{Nephrotoma glabricristata sp. $\mathrm{n}$.}

Allied to ferruginea; basal three antennal segments yellow, the succeeding segments varying from uniformly black to weakly bicolorous; mesonotal praescutum yellow with three more nacreous stripes that are very narrowly bordered in part by dark brown; 
mediotergite with a brown central stripe on anterior half; wings narrow, with a faint brown tinge, the stigma and costal border darker; wing-tip and seams along veins darkened; a few macrotrichia in outer end of cell $R_{3}$; abdomen orange, sparsely patterned with darker; male hypopygium with the dorsal crest of the inner dististyle high and entirely glabrous.

Male.-Length about $10 \mathrm{~mm}$.; wing $9.5-10 \mathrm{~mm}$.; antennae about $3.3 \mathrm{~mm}$.

Female.-Length about $15 \mathrm{~mm}$; wing 11-11.5 mm.

Frontal prolongation of head polished yellow; nasus distinct; palpi yellow, the terminal segment a little darker. Antennae relatively short; basal three segments yellow, succeeding segments varying from uniform biack to weakly bicolored, with the basal enlargement of the segment blackened, the apex paler (this latter condition in holotype); flagellar segments rather strongly incised. Head orange; occipital brand of moderate size, elongate oval, with the anterior end pointed, poorly defined.

Pronotum darkened laterally, clear light yellow medially above. Mesonotal praescutum yellow, with three more nacreous stripes that are very narrowly bordered by dark brown; on the lateral stripes this border is restricted to inner margin; lateral stripes straight, without clearly defined marginal marking opposite anterior end; scutum yellow, each lobe entirely traversed by posterior extensions of the lateral praescutal stripes, these not margined with darker; scutellum darkened, parascutella pale; mediotergite yellow, with a brown central stripe that is narrowed or obliterated on posterior half, posterior border of sclerite narrowly darkened. Pleura yellow, variegated with reddish brown, especially on propleura and on ventral anepisternum, sternopleurite, meron and pleurotergite. Halteres with stem obscure yellow, knob infuscated. Legs with the coxae reddish yellow; trochanters yellow; femora yellow, the tips very narrowly blackened; tibiae pale yellowish brown, passing into dark brown; tarsi black. Wings narrow, with a faint brown tinge; cell $S c$ and stigma brown, cell $C$ and prearcular field more yellowish brown; wing-tip and very narrow seams along cord brown; a brown seam along vein $C u$; veins dark brown, narrowly and vaguely seamed with brown. A few macrotrichia in outer end of cell $R_{5}$, with a few others at proximal end of stigma. Venation: $S c_{2}$ ending opposite origin of the short oblique $R s$, the latter in virtual alignment with $R_{4}+_{5}$; cell $M_{1}$ narrowly sessile. 
Abdomen orange, both tergites and sternites with a faint dusky median spot shortly before apex; hypopygium orange. Male hypopygium of the general type of ferruginea; inner dististyle with the dorsal crest unusually high and entirely glabrous; in ferruginea, the entire margin is provided with abundant short setae.

Habitat.-Cuba, Hispaniola.

Holotype, ô, Loma del Gato, Sierra del Cobre, Oriente, Cuba, altitude about 3,000 feet, July 3-7, 1936 (Darlington). Allotopotype, + , Buenos Aires, Santa Clara, Cuba, July 19, 1932 (Bates \& Fairchild). Paratopotype, ô; paratypes, $1 \hat{o}, 2$ 우, with allotype, July 19-20, 1932; ô o , Kenskoff, near Port-au-Prince, Haiti, altitude 4,000-6,000 feet, September 2, 1934 (Darlington); La Visite and vicinity, La Selle Range, Haiti, altitude 5,000-7,000 feet, September 16-23, 1934 (Bates); Loma Rucilla, Dominican Republic, altitude 5,000-10,000 feet, June 8, 1938 (Darlington).

Nephrotoma glabricristata is closest to $N$. ferruginea (Fabricius) and allies, especially to the southern Nearctic $N$. ferruginea suturalis (Loew). It differs especially in the coloration, narrow wings, and structure of the male hypopygium, as above described. I had earlier (Journ. Dept. Agr. Puerto Rico, 16:378; 1932) recorded this species as a variety of ferruginea but with the present abundant material it appears to be quite distinct. In the Hispaniolan material, there is a slight modification of the praescutal pattern as above described. The margins of the central praescutal stripe and the mesal edge of each lateral stripe in cases with anterior ends outcurved towards margin but entirely polished and not differentiated in color from remainder of stripe.

\section{Megistocera longipennis (Macquart).}

Cuba: Santiago de las Vegas, May 22, 1931, October 3, 1929 (Otero); July 12, 1930 (Bruner).

\section{Brachypremna unicolor Osten Sacken.}

Cuba: San Blas, Santa Clara, Trinidad Mountains, altitude 700 feet, July 26; December 23, 1931 (Rowe).

Puerto Rico: One $\delta$, without further data, ex Winthem Collection in the Vienna Museum.

Dolichopeza (Megistomastix) devexa Alexander.

Cuba: North side of the Pico Turquino, Sierra Maestra, Oriente, altitude 4,500-6,000 feet, June 18-20, 1936 (Darlington). 


\section{Dolichopeza (Megistomastix) darlingtoni sp. n.}

General coloration dark brown, the praescutum more reddish brown; antennae (male) short, less than one-half the length of body, verticils short; legs black, the femoral bases narrowly yellow; wings strongly darkened, the stigma dark brown; abundant macrotrichia in cells of outer three-fourths of wing; abdominal segments weakly bicolored, yellowish brown, the incisures narrowly blackened; male hypopygium with eighth sternite produced into a long median lobe that terminates in a trident of black spines; median area of ninth tergite somewhat similarly produced into a long lobe bearing coarse setae; outer dististyle with the outer lobe narrow.

Male.-Length about $10 \mathrm{~mm}$; wing $9.5 \mathrm{~mm}$; antennae about $4 \mathrm{~mm}$.

Frontal prolongation of head short, black; palpi black. Antennae black, the pedicel obscure yellow; flagellum relatively short, less than one-half the length of body; segments cylindrical, with verticils that are shorter than the segments; pubescence of segments short and inconspicuous. Head brownish black, the anterior vertex paler, relatively narrow, less than two times the diameter of scape.

Mesonotal praescutum almost uniformly dark reddish brown, with indications of a median and shorter lateral brown stripes; humeral and lateral portions of praescutum more blackened; posterior sclerites of notum dark brown, the median region of scutum and scutellum a little paler; mediotergite and pleurotergite more reddish brown. Pleura brownish black. Halteres with stem and apex of knob obscure yellow, base of knob weakly darkened. Leg's with coxae dark brown; trochanters yellow; remainder of legs black, the femoral bases very narrowly yellow. Wings strongly darkened, especially the costal border and outer radial field; stigma darker brown; veins and trichia brownish black. Macrotrichia of cells abundant, including all but the basal fourth of wing and involving the distal half of cell 2nd $A$. Venation: $R_{1}+_{2}$ preserved as a weak spur; petiole of cell $M_{1}$ a little shorter than $m$; cell 1 st $M_{2}$ long and narrow, a trifle widened outwardly but still approximately parallel-sided.

Abdominal segments weakly bicolored, yellowish brown, the incisures narrowly blackened, involving both the apices and bases of the individual segments; hypopygium darkened. Male hypopygium (Fig. 11) with the eighth sternite, $8 s$, produced into an elongate median lobe that is tipped with three conspicuous black spinous setae. Ninth tergite, $9 t$, somewhat similarly produced into a long median lobe that is a little expanded at distal end and provided with 
long coarse setae; lateral tergal lobes low, with a close group of about a dozen setae. Basistyle, $b$, produced into a conspicuous lobe that bears numerous short black spines at apex, with a few longer spines along mesal face. Outer dististyle, od more elongate than in devexa, especially the narrow outer lobe, the inner mesal lobe slender, provided with blackened setae. Beak of inner dististyle, $i d$, small.

Habitat.-Cuba (Oriente).

Holotype, $\hat{\delta}$, Pico Turquino, Sierra Maestra, north side, altitude 4,500-6,000 feet, June 18-20, 1936 (Darlington).

Named in honor of the collector, Dr. P. J. Darlington, Jr. The nearest ally is Dolichopeza (Megistomastix) devexa Alexander, which is well-distinguished by the elongate antennae that are more than twice as long as in the present fly. The structure of the male hypopygium differs in all details. The somewhat remarkable lobe of the eighth sternite of the present fly is represented in devexa by a smaller pale unarmed lobe.

\section{Dolichopeza (Megistomastix) domingensis sp. $\mathrm{n}$.}

General coloration dark gray; antennae relatively short, black, with inconspicuous verticils and pubescence; pleura variegated yellow and brownish black; halieres black; leg's black, the femoral bases restrictedly obscure yellow; wings strongly infuscated, the stigma darkened; certain of the veins seamed with brown; obliterative areas at cord conspicuous; macrotrichia of cells abundant, present on distal three-fourths of wing; $R_{1}+_{2}$ entire; cell $M_{1}$ sessile; abdominal tergites black, the lateral margins obscure yellow; male hypopygium with the inner dististyle unusually broad, its apex obtuse; eighth sternite with the median lobe low and obtuse, without modified spines or setae.

Male.-Length about $9 \mathrm{~mm}$; wing $10.8 \mathrm{~mm}$; antennae about $3.6 \mathrm{~mm}$.

Rostrum obscure brownish yellow; palpi black. Antennae relatively short, black, the pedicel a little brightened; flagellar segments subcylindrical, the verticils much shorter than the segments, pubescence short. Head dark brown.

Pronotum dark brown. Pretergites and humeral region of praescutum restrictedly pale. Disk of praescutum covered by confluent dark gray stripes, obliterating the interspaces and restricting the brownish black ground to the lateral borders; scutal lobes dark gray, slightly variegated by blackish, the median area narrowly pale; scutellum polished black, the parascutella pale, slightly marked with 
darker; mediotergite brown, more blackened laterally. Pleura yellow, variegated with brownish black areas, especially on the propleura and anepisternum and again on the ventral sternopleurite and meron; a dark spot on ventral pleurotergite. Halteres black, the base of stem restrictedly yellow. Legs with coxae and trochanters yellowish testaceous; remainder of legs black, the femoral bases restrictedly obscure yellow. Wings (Fig. 2) strongly infuscated, the stigma darker; cells $C$ and $S c$, together with a seam on $m-c u$, a little darker than the ground; conspicuous whitish obliterative areas before stigma and especially across bases of cells $1 s t M_{2}$ and $M_{3}$; veins beyond cord and tip of 2nd $A$ rather insensibly seamed with darker; veins and trichia dark brown. Macrotrichia of cells abundant, including virtually the whole wing with the exception of the proximal fourth (represented in figure by stippling); in the outer cells where the veins are seamed with darker, the trichia are more restricted to the centers of the cells. Venation: $R_{1}+_{2}$ entire; $R s$ short, oblique, subequal to basal section of $R_{4}+_{5}$; cell $M_{1}$ broadly sessile.

Abdomen with tergites black, paling to obscure yellow on sides; sternites chiefly yellow, the incisures darkened, more especially involving the bases of the segments. Male hypopygium (Fig. 12) with lobe of eighth sternite, $8 s$, very low and broad, provided only with normal setae. Caudal margin of ninth tergite, $9 t$, generally transverse to very feebly emarginate, with abundant coarse black setae. Region of basistyle, $b$, with coarse black spines that are continued based on the face of style. Outer dististyle, od, scarcely modified. Inner dististyle, id, with the blade very broad, the apex obtuse.

Habitat.-Dominican Republic.

Holotype, ô, Loma Rucilla, altitude 5,000-10,000 feet, June 1938 (Darlington).

Dolichopeza (Megistomastix) domingensis is so distinct from the other described species of the subgenus that it requires little comparison. It is the only species having vein $R_{1}+{ }_{2}$ entire and cell $M_{1}$ sessile. The structure of the male hypopygium is somewhat unusually generalized. The subgenus Megistomastix had not hitherto been recorded from Hispaniola though represented by somewhat numerous species in Puerto Rico and Cuba.

\section{Limonia (Discobola) gowdeyi (Alexander).}

Cuba: San Blas, Santa Clara, Trinidad Mountains, altitude 700 feet, July 1926, December 4, 1931 (Rowe). Pico Turquino, Sierra Maestra, Oriente, south side, altitude 3,000-5,000 feet, June 1936 (Darlington). 


\section{Limonia (Limonia) hoffmani Alexander.}

Puerto Rico: El Semille, Villalba, altitude 1,600 feet, at light, January 26, 1935 (W. A. Hoffman).

Limonia (Limonia) umbrata (de Meijere).

Dicranomyia umbrata de Meijere, Tijd. voor Ent., 54; 25-26; 1911.

Limonia fissitis Alexander, Ann. Ent. Soc. America, 19:159; 1926.

Widely distributed in eastern Asia. Apparently introduced by commerce into the Neotropical Region. The type-locality of fissitis is Vera Cruz, Mexico.

Cuba: Sierra Rangel, Pinar del Río, altitude 1,500 feet, 1936 (Brother Chrysogone, Colegio de la Salle, Havana).

\section{Limonia (Limonia) domballah sp. n.}

General coloration of mesonotum black, the praescutum more obscure yellow and castaneous; pleura black; knobs of halteres yellow; femora yellow, narrowly ringed with black before tips; wings yellow, patterned with brown; $R s$ angulated and spúrred at origin; abdominal segments black, the caudal borders narrowly yellow.

Female.-Length about $10 \mathrm{~mm}$; wing $10 \mathrm{~mm}$.

Rostrum and palpi black. Antennae black throughout; flagellar segments oval, with very short apical necks; longest verticils a little exceeding the segments. Head with the front and narrow anterior vertex gray; remainder of vertex and the occiput black. the orbits weakly dusted with gray.

Pronotum black medially above, obseure yellow on sides. Mesonotal praescutum polished obscure yellow, more castaneous behind, with three black stripes, the median one intense only on cephalic portion, becoming obsolete at or before midlength of sclerite; lateral stripes appearing as major areas on sides of praescutum, crossing the dorsopleural region and becoming confluent with the blackened pleura; sciutal lobes black, the median area brownish yellow; scutellum and postnotum shiny black. Pleura and pleurotergite uniformly black. Halteres with base of stem and the knob obscure yellow, the distal portion of stem infuscated. Legs with the coxae yellow, the fore coxae a trifle darkened on anterior face; trochanters yellow; femora yellow, with a narrow black subterminal ring that is a little wider than the yellow apex; tibiae yellowish brown, the tips narrowly 
darkened; remainder of legs black. Wings (Fig. 3) yellow, with a conspicuous brown paitern, as follows: Extensive washes in basal cells from $S c$ to margin in cell 2nd $A$, at origin of $R s$, cord and outer end of cell 1st $M_{2}$; stigma oval, darker brown; wing-tip weakly infumed; veins brown. Vienation: $S c_{1}$ ending about opposite four-fifths the length of $R s, S c_{2}$ at its tip; a short spur of $R_{1}+_{2}$; $R s$ angulated and spurred at origin; free tip of $S c_{2}$ and $R_{2}$ in transverse alignment; inner end of cell $R_{3}$ lying far proximad of either cell $R_{5}$ or $1 s t M_{2}$; cell $1 s t M_{2}$ subequal in length to vein $M_{3}$ beyond it; $m$-cu a short distance before fork of $M$; cell $2 n d A$ wide.

Abdominal tergites black, the caudal borders of the segments narrowly ringed with yellow, on, the subterminal segments uniformly blackened; basal sternites obscure yellow, the remaining segments patterned as on the tergites. Ovipositor with the cerci relatively small and slender, gently upcurved to the acute tips.

Habitat.-Dominican Republic.

Holotype, $\hat{o}$, Loma Rucilla and mountains to north, altitude 5,000-8,000 feet, June 1938 (Darlington).

The name, Domballah, is that of the Father of the Gods of the Voodoos in Hispaniola. The species is very distinct from all described regional species, especially in the uniformly blackened pleura and in the paitern of the wings.

\section{Limonia (Dicranomyia) calliergon sp.n.}

General coloration gray, variegated with black; cephalic half of mesonotal praescutum uniformly brownish gray, the posterior half clearer gray, with four distinct black stripes; knobs of halteres black; legs black, the femoral bases yellow, broadest on fore legs; tips of all femora narrowly whitish yellow; wings whitish subhyaline, reticulately patterned with dark brown; a complete white crossband before cord; $m-c u$ oblique, before the fork of $M$, longer than the distal section of $C u_{1}$; abdomen yellow; male hypopygium with two rostral spines from a single common tubercle.

Male.-Length about 6-6.5 mm.; wing 6.4-7 mm.

Female.-Length about 7-7.5 mm.; wing 7.5-8 mm.

Rostrum and palpi black, the former a little pruinose. Antennae with scape black, pruinose; pedicel obscure yellow; basal flagellar segments brownish yellow, the outer segments passing into black; flagellar segments oval. Head black, variegated with silvery, on the anterior vertex a little more golden pollinose. 
Mesonotal praescutum gray, the cephalic half more uniformly brownish gray, unstriped; on posterior half with four clearly defined black stripes, the intermediate pair not reaching the suture, the laterals fused with the clark lateral margin, crossing the suture and suffusing most of the scutal lobes; median area of scutum and the scutellum broadly light gray, parascutella dark; mediotergite chiefly blackened, variegated with gray on sides; lateral borders of pronotum and praescutum blackened. Pleura gray, variegated with velvety black, especially on anepisternum, dorsal pteropleurite and pleurotergite. Halteres with stem pale yellow, knob black. Legs with fore coxae blackened, remaining coxae more pruinose; trochanters brown; femora black, the bases light yellow, more extensively so on fore legs where about the basal third is included, less so on the middle and posterior leg's where only about the proxinfal eighth is involved; tips of all femora narrowly but very conspicuously whitish yellow, the amount subequal on all legs; remainder of legs black. Wings with the ground color whitish subhyaline, handsomely patterned with dark brown on cephalic portion and more grayish brown behind; pattern more or less reticulate, with a complete white crossband before cord; before the cord with from nine to twelve costal dark rays, cell $S c$ uniformly darkened; in cell $R$ at base, before mid-distance to origin of $R s$ and at the origin of the latter with dark lines that reach vein $M$ behind or virtually so; beyond the cord and stigma a similar muscoid pattern that sends about four or five rays to costal border at stigma and about three or four others to above the termination of vein $R_{3}$, these latter areas extensively darkened and fused behind in the proximal portion of the outer radial field; posterior cells of wing more sparsely reticulate with grayish brown, chiefly evident as marginal rays in all the cells; cells adjoining vein $C u$ slightly suffused with brown; prearcular field slightly more yellow; veins pale, darker in the patterned areas. Venation: $R s$ angulated and more or less spurred at origin; $S c_{1}$ extending a short distance beyond origin of $R s$ to near one-fourth the length, $S c_{2}$ close to tip; cell 1 st $M_{2}$ relatively large, longer than any of the veins beyond it; $m$-cu oblique, before the fork of $M$, longer than the distal section of $C u_{1}$; cell and $A$ wide.

Abdomen conspicuously pale yellow; in cases, the subterminal segments more weakly infuscated; hypopygium yellow. Male hypopygium with the tergite transverse, the caudal margin gently emarginate. Dorsal dististyle a gently curved sickle, the long drawn tip acute. Ventral dististyle fleshy, a little larger than the basistyle; 
rostral prolongation stout, on outer margin beyond midlength with a single tubercle that bears two subequal spines, these latter about twice as long as the tubercle. Gonapophyses with mesal-apical lobe stout, with a coarsely and irregularly serrated lateral flange.

Habitat.-Haiti.

Holotype, $\hat{\delta}$, La Visite and vicinity, La Selle Range, altitude 5,000-7,000 feet, September 16-23, 1934 (Bates). Allotopotype, ㅇ. Paratopotypes, 10 ô $q$.

A very distinct species, superficially resembling species like $L i$ monia (Dicranomyia) reticulata (Alexander) or $L$. (D.) pampoecila (Alexander), yet entirely distinct. I am placing it in the subgenus Dicranomyia despite the fact that $S c_{1}$ ends a short distance beyond the origin of $R s$, as in Limonia, s.s.

Limonia (Dicranomyia) calliergon polygrapha subsp.n.

Male.-Length about $6 \mathrm{~mm}$; wing $7 \mathrm{~mm}$.

Close to týpical calliergon, differing as follows:

Scutellum with darkened extensions from the scutal lobes, on either side of median line. Femora more extensively yellow, with moderately broad, black, nearly terminal rings; tibiae yellow, the bases narrowly black, the tips and all tarsi broken. All legs of the unique type are detached and thus cannot be safely associated with any given trochanter. Wings with the dark reticulate pattern much more extensive, the costal rays narrow and entire; cells $R$ and $M$ with darkened areas, as in the other cells; white crossband before cord narrower and less evident; veins dark, including those in the ground areas, and therefore much more distinct. Male hypopygium with the ventral dististyle smaller than in the typical form, the rostral spines arising from a similar conspicuous basal tubercle but unequal in length, the outer about three-fourths the length of the inner and closely applied. to it.

Habitat.-Dominican Republic.

Holotype, $\hat{o}$, Valle Nuevo, southeast of Constanza, altitude about 7,000 feet, August 1938 (Darlington).

Although the coloration of the thorax and general pattern of the wing's is very similar in the two forms, the differences in the color of the legs and wings, and the nature of the rostral spines of the male hypopygium, in the present fly, incline me to believe that it may be found to represent a valid species rather than a subspecies. 
Limonia (Dicranomyia) reticulata (Alexander).

Cuba: San Blas, Santa Clara, Trinidad Mountains, August 12, 1932 (Bates \& Fairchild). Sierra Rangel, Pinar del Río, January 27-30, 1931 (Acuña \& Otero).

\section{Limonia (Dicranomyia) indefensa sp.n.}

General coloration medium brown, the praescutum unpatterned; antennae black throughout; halteres black, the base of stem yellow; legs dark brown, the femoral tips not brightened; wings with a brown tinge, the oval stigma darker brown; vague brown seams along cord and outer end of cell 1 st $M_{2}$; abdominal tergites dark brown, the sternites weakly bicolored, reddish brown, the outer half of the segments darker.

Female.-Length about $9 \mathrm{~mm}$.; wing $9.3 \mathrm{~mm}$.

Rostrum and palpi black throughout; flagellar segments longoval. Head black; anterior vertex about equal in width to the diameter of the scape.

Pronotum brown. Mesothorax almost uniformly medium brown, without markings, the pleura scarcely paler. Halteres black, base of stem pale. Legs with the coxae pale brown; trochanters greenish testaceous; remainder of legs dark brown, the femoral tips not brightened. Wing's with a brown tinge, the oval stigma darker brown; paler brown, poorly defined seams on cord and outer end of cell 1st $M_{2}$; veins pale brown. Venation: $S c_{1}$ ending just beyond origin of $R s, S c_{2}$ shortly before this point; free tip of $S c_{2}$ and $R_{2}$ in transverse alignment; cell 1st $M_{2}$ subequal in length to the longest veins beyond it; $m$-cu close to fork of $M$.

Abdominal tergites dark brown; sternites weakly bicolored, reddish brown basally, the outer half of each segment somewhat darker. Ovipositor with cerci slender, very gently upcurved.

Habitat.-Haiti.

Holotype, + , La Visite, La Selle Range, altitude 5,000-7,000 feet, September 16-23, 1934 (Bates).

Limonia (Dicranomyia) indefonsa is quite distinct from the other regional species of the subgenus. It is apparently closest to $L$. (D.) humidicola (Osten Sacken) and allies, differing in the coloration of the body and wings, and in the uniformly darkened femora.

Limonia (Dicranomyia) divisa Alexander.

Haiti: La Visite and vicinity, La Selle Range, altitude 5,000-7,000 feet, September 16-23, 1934 (Bates). 
Puerto Rico: El Semille, Villalba, altitude 1,600 feet, at light January 26, 1935 (W. A. Hoffman).

Limonia (Neotimnobia) diva (Schiner), var.

Cuba: Sierra Rangel, Pinar del Río, January 27-30, 1931 (Acuña \& Otero).

\section{Limonia (Rhipidia) schwarzi (Alexander).}

Cuba: Sierra Rangel, Pinar del Río, January 27-30, 1931 (Acuña \& Otero).

Jamaica: Balaclava (A. E. Wight).

Limonia (Rhipidia) domestica (Osten Sacken).

Cuba: San José, July 7 (at light). Santiago de las Vegas, April 7, 1930 (Otero). San Blas, Santa Clara, Trinidad Mts., altitude 700 feet, January 1, 1932 (Rowe). Sierra Rangel, Pinar del Río, January 27-30, 1931 (Acuña \& Otero).

Puerto Rico: El Semille, Villalba, altitude 1,600 feet, at light, January 26, 1935 (Hoffman).

Jamaica: Balaclava; Moneague, February 2-3 (W. S. Brooks). Port Antonio, (A. E. Wight).

Limonia (Geranomyia) antillarum Alexander.

Cuba: Buenos Aires, Santa Clara, Trinidad Mountains, May 14, 1932 (Acuña).

Puerto Rico: El Semille, Villalba, altitude 1,600 feet, at light, January 26, 1935 (Hoffman).

Limonia (Geranomyia) myersiana Alexander.

Cuba: San Blas, Santa Clara, Trinidad Mountains, altitude 700 feet, December 4, 1931 (Rowe). Sierra Rangel, Pinar del Río, January 27-30, 1931 (Acuña \& Otero).

Puerto Rico. El Semille, Villalba, altitude 1,600 feet, at light, January 26, 1935 (Hoffman).

\section{Limonia (Geranomyia) tibialis (Loew).}

Cuba: San Blas, Santa Clara, July 20, 1932 (Bates \& Fairchild). Sierra Rangel, Pinar del Río, January 27-30, 1931 (Acuña \& Otero).

Puerto Rico: El Semille, Villalba, altitude 1,600 feet, at light, January 26, 1935 (Hoffman).

Jamaica: Balaclava (A. E. Wight). Port Antonio (A. E. Wight). 
In the Port Antonio specimen the praescutal stripes are obsolete or nearly so, but the identity seems certain. Whether the species is the same as the earlier $L$. (G.) intermedia (Walker) remains in question yet is entirely possible.

\section{Limonia (Geranomyia) banksiana sp. n.}

Allied to canadensis; general coloration of praescutum medium brown, without stripes; scutellum brown, with a vague central paler area; mediotergite dark brown, the apical portion yellow; legs brown; wings subhyaline, unmarked except for the oval, pale brown stigma; $S c_{1}$ ending about opposite midlength of $R s ; r-m$ greatly reduced by the approximation of veins $R_{4}+_{5}$ and $M_{1}+_{2}$; male hypopygium with the lobes of ninth tergite rounded, provided with conspicuous setae, the extensive median area glabrous; ventral dististyle large and fleshy; rostral prolongation short, with two subequal spines arising from very unequal tubercles, the shortest one close to apex of prolongation; mesal-apical lobe of gonapohysis entirely pale, simple, nearly straight.

Male.-Length, excluding rostrum, about $6 \mathrm{~mm}$; wing $6.4 \mathrm{~mm}$; rostrum approximately $2.6 \mathrm{~mm}$.

Rostrum relatively long, brown, the tips of paraglossae darker brown. Antennae dark brown, the scape a little paler brown. Head grayish brown; anterior vertex narrow, subequal to diameter of scape.

Mesonotal praescutum medium brown, without stripes; humeral region a little more yellowish; scutal lobes pale brown, the median area pale yellow; scutellum brown, with a vague central paler area; mediotergite dark brown, with less than the apical half yellow. Pleura brownish yellow, unmarked. Halteres pale. Legs with the coxae and trochanters obscure yellow, the fore coxae a trifle darker; remainder of legs pale brown, the terminal tarsal segments dark brown. Wings, subhyaline, the oval stigma pale brown; veins brown. Numerous macrotrichia on veins beyond cord, as well as a complete series on Rs. Venation: $S c$ relatively long, $S c_{1}$ ending about opposite midlength of $R s, S c_{2}$ a short distance from its tip; $r-m$ greatly reduced by the approximation of veins $R_{4}+_{5}$ and $M_{1}+_{2} ; m$-cu close to fork of $M$; cell 2 nd $A$ relatively narrow.

Basal abdominal segments brown, the outer segments somewhat more bicolored, darker brown at apex than at base; hypopygium dark. Male hypopygium (Fig. 14) with the outer angles of ninth 
tergite, $9 t$, produced into rounded lobes that are provided with conspicuous setae, the extensive intermediate area glabrous. Ventromesal lobe of basistyle large. Ventral dististyle, $v d$, large and fleshy, much more extensive than the basistyle; rostral prolongation short, with two spines arising from unequal tubercles; outer spine placed very close to apex of prolongation on a low tubercle; second spine subequal in length, arising a little farther basad and from a much longer tubercle that exceeds one-third the length of spine. Mesalapical lobe of gonapophysis, $g$, entirely pale, simple, nearly straight.

Habitat.-Cuba.

Holotype, ồ, Soledad, near Cienfuegos, August 6, 1920 (Banks).

I take very great pleasure in naming this fly in honor of the collector, Dr. Nathan Banks, to whom I am greatly indebted for many appreciated favors. ${ }^{\bullet}$ Although generally similar in its general appearance to Limonia (Geranomyia) canadensis (Westwood), the present fly is very distinct in the structure of the male hypopygium.

Limonia (Geranomyia) subvirescens Alexander.

Cuba: Loma de la Sierra, Santiago de las Vegas, March 5, 1931 (Acuña \& Otero).

Limonia (Geranomyia) subvirescens jamaicae subsp.n.

Male.-Length, excluding rostrum, about $5 \mathrm{~mm}$; wing $5 \mathrm{~mm}$.; rostrum about $3 \mathrm{~mm}$.

Female.-Length, excluding rostrum, about $6 \mathrm{~mm}$.; wing $5.8 \mathrm{~mm}$; rostrum about $3 \mathrm{~mm}$.

Rostrum pale yellowish brown, the tips of the paraglossae strongly recurved. Antennae dark brown throughout; flagellar segments oval. Head dark brown.

Thorax uniform orange yellow, unmarked. Halteres pale. Legs yellow throughout. Wings pale yellow, the subcircular stigma pale brown; veins brownish yellow. Venation: $S c$ moderately long, $S c_{1}$ ending about opposite two-thirds the length of $R s, S c_{2}$ at its tip; Rs about twice the basal section of $R_{4}+_{5} ; m$-cu at fork of $M$; cell 2nd $A$ relatively narrow.

Abdomen yellow. Male hypopygium much as in typical subvirescens Alexander (Cuba) but apex of rostral prolongation of ventral dististyle much more slender, the diameter at this point only about one-third the length of the rostral spines. In subvirescens, the transverse diameter beyond the rostral spines is more than one-half the length of the spines. 
Habitat.-Jamaica.

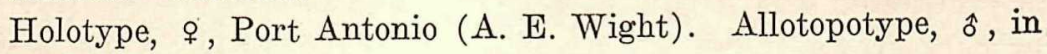
poor condition.

In typical subvirescens, the wings are subhyaline, with the brown veins much more distinct.

\section{Limonia (Geranomyia) virescens (Loew).}

Puerto Rico: El Semille, Villalba, altitude 1,600 feet, at light, January 26, 1935 (Hoffman).

Orimarga (Diotrepha) mirabilis (Osten Sacken).

Cuba: Santo Tomás, Province of Zapata, May 5-9, 1927 (Acuña \& Bruner).

Helius (Helius) albitarsis (Osten Sacken).

Cuba: Sierra Rangel, Pinar del Río, altitude 1,500 feet, April 26, 1933 (Bruner \& Otero); January 27-30, 1931 (Acuña \& Otero).

Ephiphragma (Epiphragma) cubensis Alexander

Cuba: Sierra Rangel, Pinar del Río, January 27-30, 1931 (Acuña \& Otero).

\section{Epiphragma (Epiphragma) auricosta sp.n.}

General coloration brown and yellow; antennae (male) short, black; first flagellar segment yellow; femora yellow, with three black rings; tibiae chiefly dark brown to black, the tarsi paling to obscure yelow; wings yellow, the cephalic third more saturated, butter-yellow, with an ocelliform pattern.

Male.-Length about 9-10 mm.; wing 11-12 mm.; antennae about $2.3-2.4 \mathrm{~mm}$.

Female.-Length about 12-13 mm.; wing 11.5-12 $\mathrm{mm}$.

Rostrum dark brown; palpi black. Antennae short, black, the basal segment of flagellum yellow; flagellar verticils exceeding the segments in length. Head chestnut brown, with a dark brown transverse band across anterior vertex and a less distinct median darkening on posterior vertex; posterior portions of vertex more or less white pruinose.

Pronotum dark brown, more yellowish on sides. Mesonotal praescutum with the ground color reddish brown, with three conspicuous, dark brown stripes on cephalic half, on posterior half becoming obseured and confluent, more uniformly dark brown; humeral regions 
of praescutum restrictedly pale, more extensively bordered internally by dark brown, the lateral margins behind the pseudosutural foveae broadly dark brown; in still other specimens, the color of the praescutum varies from uniform dark brown to striped with dark throughout the length; scutum chiefly brownish yellow, contrasting abruptly with the praescutum; scutellum and postnotum dark colored, light gray pruinose, the mediotergite and pleurotergite with their posterior borders broadly dark brown. Pleura with the propleura and pleurotergite chiefly dark brown, the mesopleura almost uniformly pale. Halteres elongate, stem obscure yellow, knob brown. Legs with the coxae obscure brownish yellow; trochanters yellow; femora yellow, with three black rings, the last terminal, the median one about twice as wide as the yellow rirg on either side; basal dark ring narrow and somewhat paler; tibiae dark brown to black, in cases the extreme tips reddish; basitarsi dark brown, remainder of tarsi paling to obscure brownish yellow. Wings with the ground color yellow, the cephalic third more saturated butter-yellow; a conspicuous, chiefly ocelliform, dark pattern, including ocelli beyond arculus, origin of $R s$, cord, outer end of cell 1st $M_{2}$ and fork of $M$; in region of stigma, several small, more blackish areas; a solidly darkened mark in cells $C u$, 1st $A$ and $2 n d A$, in alignment with the ocellate area at origin of $R s$; areas in cell 2 nd $A$ about three in number, the intermediate ones in cases interconnected; veins brown, more yellowish in the costal interspaces. Venation: $m$-cu not more than its own length beyond the fork of $M$.

Abdominal tergites dark brown, the caudal margins broadly more grayish; sternites and hypopygium more yellow to brownish yellow. Male hypopygium with the lobes of the tergite obtusely rounded, separated by a deep linear notch. Interbases with short triangular apical points.

Habitat.-Dominican Republic.

Holotype, $\hat{o}$, Valle Nuevo, southeast of Constanza, altitude about, 7,000 feet, August 1938 (Darlington). Allotopotype, ㅇ. Paratopotype, 1 \% ; paratypes, 1 sex?, Foothills of the Cordillera Central, south of Santiago, June 1938; 1 s, Loma Rucilla, altitude 8,00010,000 feet, June 1938 (Darlington).

Epiphragma (Epiphragma) auricosta is very different from the three other species known from the Greater Antilles, especially in the strongly yellow wings and the pattern of the legs, as the three-banded femora and darkened tibiae. 
Epiphragma (Epiphragma) buscki Alexander.

Haiti: Desbarriere, Mt. La Hotte, altitude about 4,000 feet, October 12-14, 1934 (Darlington).

\section{Epiphragma (Epiphragma) inornatipes sp.n.}

General coloration of praescutum brownish yellow, the cephalic fourth darkened, the remainder with narrow brown stripes; pleura gray pruinose, the dorsopleural region and membrane dark brown; femora almost uniformly brown, the tips narrowly pale, tibiae and tarsi yellow; wings whitish subhyaline, patterned with brown, much as in solatrix; dark areas in outer radial field large and full, dark areas in cell 2nd $A$ very extensive, involving the central portion of cell; male hypopygium with the inner dstistyle relatively narrow, with conspicuous setae.

Male.-Lengih about $11.5 \mathrm{~mm}$; wing $12.3 \mathrm{~mm}$.

Rostrum brown; palpi black. Antennae with scape and pedicel black, flagellum broken. Head chiefly brown, the posterior orbits more grayish; anterior vertex behind antennae more blackened.

Pronotum light brown, narrowly blackened medially, more broadly so on sides. Mesonotal praescutum with cephalic fourth almost uniformly darkened, the remainder more brownish yellow with four narrow brown stripes that do not reach the suture behind, the lateral pair much reduced; lateral borders of praescutum behind pseudosutural fovea more uniformly darkened, the suture bordered by brown; scutum with cephalic half buff, the posterior half almost covered by a transverse brown band; scutellum buffy; mediotergite pale, the posterior third and a narrow transverse line at near midlength darker brown. Pleura chiefly gray pruinose, variegated with brownish black, especially on dorsal pleurites and the dorsopleural region. Halteres with stem yellow, knob more or less darkened, the apex narrowly pale. Legs with the coxae gray, the extreme base of fore pair darkened; trochanters yellow; femora almost uniform brown, paler basally, the apex narrowly pale; tibiae and tarsi yellow. Wings whitish subhyaline, heavily patterned with brown, the areas of cephalic and apical portions paler brown with narrow dark borders; in Anal field, the areas uniformly dark brown; stigma narrow, almost uniformly dark brown; wing pattern somewhat as in solatrix yet differing in certain important points; dark areas in cell $C$ more extensive than the interspaces; marginal areas in outer radial field large and full; dark areas in cell 2nd $A$ very extensive, involving the ceniral portion of cell. 
Abdominal segments variegated dark and paler brown, the lateral borders buffy. Male hypopygium with the outer dististyle relatively narrow, the tip decurved; inner dististyle narrower than in solatrix, provided with conspicuous setae. Interbases with apical spines recurved.

Habitat.-Cuba.

Holotype, ô, Pico Turquino, Sierra Maestra, Oriente, north side, altitude 4,500-6,000 feet, June 18-20, 1936 (Darlington).

Epiphragma (Epiphragma) inornatipes is apparently closest to the smaller $E$. (E.) solatrix (Osten Sacken), having the pattern of the femora virtually the same. It differs in the coloration of the lody and wings, and in the details of structure of the male hypopygium.

\section{Shaînonomyia batesi sp. n.}

Belongs to the mesophragma group; mesonotum gray; halteres pale yellow; femora yellow with a brownish black subterminal ring, on fore and middle femora with the basal third or more similariy blackened; wings yellow, spotted and dotted with brown; cell $1 s t M_{2}$ closed, elongate, with $m$-cu at near one-third the length.

Male.-Length about $5.5-6 \mathrm{~mm}$; wing $6-6.5 \mathrm{~mm}$.

Female.-Length about 7.5-8 $\mathrm{mm}$; wing $6.5-7 \mathrm{~mm}$.

Rostrum and palpi black. Antennae yellow, the outer flageliar segments infuscated; in darker individuals the antennae are more uniformly brown throughout; flagellar segments oval. Head gray.

Mesonotum gray, the praescutum with a slightly darker gray median stripe, the seutal lobes similarly darkened. Pleura black, gray pruinose. Halteres pale yellow throughout. Legs with the coxae black, pruinose; trochanters yellow; femora yellow, with a conspicuous, dark brown to brownish black ring before the subequal or narrower yellow apex; fore and middle femora with the basal third or more similarly blackened, leaving only a relatively narrow, obscure yellow ring between the two dark bands; posterior femora less distinctly or not at all darkened at base; tibiae and tarsi yellow, the tips of the latter darkened. The females seem to have darker leg's than the males and at least one specimen has the fore and middle femora uniformly blackened with the exception of the narrow yellow bases; hind femora less evidently blackened except at tips; in all cases the fore and middle femora are more extensively blackened than are the posterior femora. Wings (Fig. 4) with the ground color yellow, the prearcular and costal fields a little deeper yellow to brownish yellow; a heavy spotted and dotted brown pattern, the 
largest areas at stigma, more or less confluent with a seam along cord; smaller brown spots at origin of $R s$, supernumerary crossvein in cell $R, m$-cu and outer ends of veins $R_{3}$ and $R_{4}$; small brown marginal spots at ends of longitudinal veins, usually more extensive at $2 n d A$; numerous to somewhat sparse brown dots in most cells of wing; veins yellow, darker in the clouded areas. Venation: $S c_{1}$ ending at near two-thirds the length of $R s, S c_{2}$ near its tip; a supernumerary crossvein in cell $R$ connecting with $R s$ about its own length beyond origin; $r-m$ strongly bowed; cell $1 s t M_{2}$ closed, elongate, longer than any of the veins beyond it; $m$-cu at near one-third the length; basal section of $M_{3}$ variable in length, from short and nearly straight to arcuated or even feebly angulated.

Abdomen black, sparsely pruinose; hypopygium reddish brown. Habitat.-Haiti.

Holotype, ô, La Visite and vicinity, La Selle Range, altitude 5,000-7,000 feet, September 16-23, 1934 (Bates). Allotopotype, 오. Paratopotypes, 9 후 우.

I take great pleasure in naming this very distinct fly in honor of the collector, Mr. Marston Bates. The species and the two next described are the first species of the genus to be discovered in Hispaniola. By my key to the Cuban members of the genus (Journ. Agr. Univ. Puerto Rico, 21:526-527; 1937), the present fly runs to Shannonomyia phragmophora Alexander. It differs from all three Cuban members of the group in the numerous dots in the cells of the wings and in the heavy dark pattern of the femora.

\section{Shannonomyia haitensis sp. $\mathrm{n}$.}

General coloration gray, the praescutum with vaguely darker stripes; basal three antennal segments yellow, the remainder black; head and pronotum clear light gray; legs yellow; wings whitish subhyaline, conspicuously patterned with brown, the areas confinod to the vicinity of the veins; $R s$ relatively short, angulated at origin; $R_{2}$ some distance before fork of cell $R_{3}$; vein $R_{4}$ strongly upcurved at tip; $r$ - $m$ strongly bowed; cell 1 st $M_{2}$ elongate.

Male.-Length about 5-5.5 mm.; wing 5-6 $\mathrm{mm}$.

Female.-Length about 6.5-7 mm.; wing 5.5-6.5 mm.

Rostrum gray; palpi black. Antennae short; basal three segments yellow, the remainder of flagellum black; flageller segments oval, much longer than the segments. Head light gray; asterior vertex relatively wide, exceeding two times the diameter of seipe. 
Pronotum clear light gray; lateral pretergites similarly clear gray. Mesonotal praescutum light gray to brownish gray, with three darker gray stripes; scutal lobes similarly darkened; scutellum gray, with a capillary brown median vitta; mediotergite gray pruinose. Pleura gray, somewhat variegated with darker gray, especially dorsally and on ventral sternopleurite. Halteres pale yellow. Legs with the coxae yellow, fore coxae a trifle darker; trochanters yellow; remainder of legs yellow, the outer tarsal segments a trifle darker. Wings (Fig. 5) whitish subhyaline, with a conspicuous pattern that is confined to the vicinity of the veins, arranged as follows: Arculus; origin of $R s$; fork of $S c$; stigma; cord and outer end of cell 1st $M_{2}$; marginal spots at ends of all longitudinal veins, smallest on $R_{5}$, largest on $2 n d A$; in cases, dark clouds at fork of $R_{2}+{ }_{3}{ }_{4}$ and at intervals along distal section of $M_{1}+{ }_{2}$; veins yellow, darker in the clouded areas. Venation: $R s$ relatively short, angulated and, in cases, short-spurred at origin; $S c_{1}$ ending at or beyond three-fourths the length of $R s ; R_{2}$ some distance before fork of cell $R_{3}$; vein $R_{4}$, and usually $R_{3}$ also, strongly upcurved at tip; $r$ - $m$ very strongly bowed; cell $1 s t M_{2}$ elongate, subequal to or longer than vein $M_{1}{ }_{2}$ beyond it; $m$-cu at from one-third to near one-half the length of the cell.

Abdomen dark brown, including the hypopygium.

Habitat.-Haiti.

Holotype, $\hat{\delta}$, La Visite and vicinity, La Selle Range, altitude 5,000-7,000 feet, September 16-23, 1934 (Bates). Allotopotype, ․ Paratopotypes, 6 ô ㅇ․

Shannonomyia haitensis is very different from the described Cuban and Puerto Rican species of the genus. It is perhaps closest to $S$. brevicula Alexander, of Cuba, differing notably in the pattern and venation of the wings.

\section{Shannonomyia septem-punctata sp. n.}

General coloration pale yellow, including the antennal flagellum, halteres and legs; wings yellow, with seven conspicuous brown spots; $R s$ unusually long, exceeding vein $R_{4}$, angulated and short-spurred at origin; $R_{2}$ shortly before fork of cell $R_{3} ; m$-cu shortly before midlength of the long cell $1 s t M_{2}$.

Female.-Length about $6.5 \mathrm{~mm}$; wing $6.2 \mathrm{~mm}$.

Rostrum and palpi brown. Antennae short; scape brown; succeeding segments pale, the outer ones a little darker; flagellar segments oval. Head brownish yellow to pale brown, darker anteriorly. 
Thorax uniformly pale yellow, virtually unmarked; central portion of scutum and adjoining median portion of praescutum somewhat clearer yellow; scutellum and mediotergite with a vague darker median vitta. Halteres pale yellow. Legs yellow, the terminal tarsal segments darkened. Wings (Fig. 6) yellow, the prearcular and costal portions a trifle more saturated yellow; seven conspicuous brown spots, as follows: At arculus; origin of $R s$; stigma; basal section of $R_{5}$; remainder of anterior cord at end of vein $M$; outer end of cell 1 st $M_{2} ; m$-cu; veins yellow, darker in the clouded areas. Venation: $R s$ unusually long, exceeding vein $R_{4}$, angulated and shortspurred at origin; $R_{2}$ subequal to $R_{1}+_{2}$, placed just before fork of cell $R_{3} ; r-m$ arcuated, lying proximad of vein $R_{5}$; cell $1 s t \mathrm{M}_{2}$ elongate, subequal to the veins beyond it, with $m$-cu shortly before midlength.

Abdomen obscure yellow, the incisures of the more basal tergites a little darker. Ovipositor with unusually long and slender valves, especially the cerci.

Habitat.-Dominican Republic.

Holotype, ô, Valle Nuevo, southeast of Constanza, altitude about 7,000 feet, August 1938 (Darlington).

Shannonomyia septem-punctata is quite distinct from all other species known from the Neotropies. The almost uniformly yellow color, conspicuously patterned wings and unusually long $R s$ will suffice for the recognition of the fly.

\section{Hexatoma (Eriocera) bruneri (Alexander).}

Cuba: Coast below Pico Turquino, Oriente, June 26-30, 1936 (Darlington). Near Santiago, September 4, 1928 (Bruner).

The first specimen listed, as well as the holotype specimen, shows a crossvein in cell $S c$ beyond the origin of $R s$, this being lacking in the second specimen above listed and evidently not entirely constant.

\section{Hexatoma (Eriocera) cubensis (Alexander).}

The female had not been described.

Female.-Length about $18 \mathrm{~mm}$; wing $15 \mathrm{~mm}$; antennae about $3 \mathrm{~mm}$.

Characters as in male, differing in the sexual characters. Antennae 9 -segmented. Ovipositor with the valves very long and slender, especially the cerci.

Allotype, + , Buenos Aires, Trinidad Mountains, Cuba, altitude 2,500-3,500 feet, May 8-14, 1936 (Darlington). 
The type males had been taken in the same locality at a somewhat lower level (altitude 1,600 feet, March 24, 1925, J. G. Myers).

\section{Hexatoma (Eriocera) juliana Alexander.}

The allotopotype and paratopotype were added to the original definition (Journ. Agr. Univ. Puerto Rico, 21:529-530; 1937) while the paper was in proof but no further data could be supplied at that time. The paratype were taken on the north side of the Pico Turquino, altitude 4,500-6,000 feet, June 18-20, 1936; the allotype at the summit, altitude 6,000 feet, June 16-21, 1936, all secured by Mr. Darlington. These specimens are smaller than the type (Male.Length about $12 \mathrm{~mm}$; wing 12.5-13.5 mm. Female.-Length about $17 \mathrm{~mm}$. ; wing $15 \mathrm{~mm}$.) but otherwise conform in all essential features. The antennae of the male are 8-segmented.

\section{Hexatoma (Eriocera) ornaticornis sp.n.}

Mesonotal praescutum reddish brown with four clearly defined dark brown stripes; antennae 7-segmented, basal four segments and apical third of last segment black, the remainder yellow; posterior sclerites of notum and the pleura dark brown to brownish black; halteres with brownish black knobs; femora yellow, the tips blackened; wings whitish hyaline, heavily patterned with dark brown, the areas in part ocelliform; margin of wing narrowly darkened; $R s$ in alignment with $R_{5}$, the basal section of the latter short; $R_{2}+_{3}$ short, only a little more than one-half $R_{2}+_{3}+_{4}$ and subequal to $R_{1}+_{2} ; m$-cu at near one-third the length of cell 1 st $M_{2}$; basal abdominal segments yellow, darkened outwardly, the distal segments, including hypopygium, brownish black.

Male.-Length about $14 \mathrm{~mm}$; wing $11.7 \mathrm{~mm}$; antennae about $2.4 \mathrm{~mm}$.

Rostrum black, sparsely pruinose; palpi black. Antennae 7-segmented; scape; pedicel, basal two flagellar segments except at incisures and distal third of terminal segment black, the remainder abruptly yellow; basal two flagellar segments more incrassated than the three outer ones; three outer flagellar segments long-cylindrical, subequal in length. Head gray; vertical tubercle moderately developed, low, on its central portion further produced into a smail lobule.

Pronotum dark brown. Mesonotal praescutum reddish brown, with four clearly defined but narrow dark brown stripes, the intermediate pair ending before the suture, the lateral pair a trifle wider, 
crossing the suture onto the scutal lobes; median region of scutum paler; scutellum testaceous brown, the parascutella darker; mediotergite testaceous brown, darker laterally, the pleurotergite more uniformly darkened. Pleura brownish black. Halteres with stem yellow, knob brownish black. Legs with coxae brownish blackened trochanters yellow; femora yellow, the tips conspicuosly blackened (about $1 \mathrm{~mm}$. or a little more); tibiae yellow, the tips brownish black; basitarsi brownish yellow, the tips and remainder of tarsi blackened. Wings (Fig. 7) with the ground color whitish hyaline, heavily patterned with dark brown, the pattern with more or less distinct ocelli at origin of $R s$, cord and outer end of cell 1 st $M_{2}$; two dark costal areas at end of $S c$ and at stigma, converging behind and uniting with darkening at cord; cell $C$ dark brown, alternating with four smaller more yellow spots; a narrow but conspicuous brown margin from beyond stigma almost to wing-base in cell 2nd $A$; a semicircular brown area across bases of cells $R$ and $M$ beyond arculus; brown washes in basal portions of outer radial field and in cells $M$, $C u$, 1st $A$ and 2nd $A$; veins brown. Numerous macrotrichia on veins beyond cord. Venation: $R s$ longer than in acunai, in alignment with $R_{5}$, the basal section of latter very short to virtually lacking; $R_{2}+_{3}$ short, only a little more than one-half $R_{2}+_{3}+_{4}$ and subequal to $R_{1}+_{2}$; cell $R_{3}$ much shorter than in acuñai; cell 1st $M_{2}$ relatively large, vein $M_{1}+_{2}$ beyond it about one-half longer than the cell; $m$-cu at near one-third the length of cell 1 st $M_{2}$, a little longer than the distal section of $C u_{1}$. No supernumerary crossvein in cell $R_{4}$, as in acuñai.

Abdomen elongate; first tergite dark brown; second segment yellow, narrowly darkened laterally, the following segments more obscure; outer segments passing through dark brown to brownish black.

Habitat.-Cuba.

Holotype, $\hat{o}$, Loma del Gato, Sierra del Cobre, Oriente, altitude about 3,000 feet, July 3-7, 1935 (Darlington).

The most similar species is Hexatoma (Eriocera) acuñai Alexander, of western Cuba, which, while having the wing-pattern somewhat similar, differs in all details of bỏdy coloration and venation.

\section{Hexatoma (Eriocera) multiguttula sp. n.}

Mesonotum dark brown, the lateral borders of praescutum very narrowly yellow; head gray, the posterior vertex with an extensive brown area; legs black, the tips of all tibiae and the entire tarsi paling to brownish yellow; wings saturated, with a conspicuous pat- 
tern of sparse brown spots and abundant dots in all the cells; $R_{2}+{ }_{3}+_{4}$ shorter than $R_{2}+_{3} ; m$-cu far distad, its caudal end more proximad than its cephalic end.

Female.-Length about $17 \mathrm{~mm}$; wing $18 \mathrm{~mm}$.

Rostrum black, gray pruinose; palpi black. Antennae (female) 9-segmented; scape and pedicel obscure yellow, sparsely pruinose above; basal two flagellar segments clear light yellow; succeeding four segments more infuscated, with their apices clearer yellow; terminal segment pale basally, the outer half darkened; first flagellar segment about one-half longer than the second; terminal segment onethird longer than the penultimate. Head light gray, the posterior vertex with an extensive brown central area; vertical tubercle low.

Pronotum light yellow, the color continued backward onto the extreme lateral border of praescutum and the dorsopleural membrane to the wing-root. Mesonotal praescutum, scutum and scutellum uniformly dark brown; mediotergite dark brown, the posterior and lateral borders a trifle pale, with a delicate pale median vitta. Pleura obscure yellow, the propleura and mesopleura somewhat infumed but not forming a stripe; ventral pleurites and pleurotergite clearer yellow. Halteres with stem obscure yellow, knob dark brown. Legs with the coxae and trochanters light yellow; femora entirely black; tibiae black, the tips paling to brown; tarsi brownish yellow. Wings saturated yellow, patterned with brown, including major areas at origin of $R s, R_{2}$, anterior cord and tip of vein $C u$; all cells with abundant small brown dots; veins yellow, darker in the major clouded areas. Venation: $S c_{1}$ ending opposite fork of $R_{2}+_{3}+_{4} ; R_{2}$ nearly as long as $R_{1}+_{2} ; R_{2}+_{3}+_{4}$ shorter than $R_{2}+_{3}$ but longer than the basal section of $R_{5}$; cell $1 s t M_{2}$ long, $m$ only about one-third as long as the basal section of $M_{3} ; m$-cu far distad, nearly twice its length beyond the fork of $M$, about one-third longer than the distal section of $C u_{1}$.

Abdominal tergites obscure yellow, more darkened medially, the extreme caudal borders of the intermediate segments yellow; sternites obscure yellow. Ovipositor with long slender cerci.

Habitat.-Dominican Republic.

Holotype, $\&$, Valle Nuevo, southeast of Constanza, altitude about 7,000 feet, August 1938 (Darlington).

The only generally similar species is Hexatoma (Eriocera) cramptoni (Alexander), known only from the Blue Mountains, Jamaica. This differs most evidently in the pattern of the thorax, unbrightened tarsi and in the details of venation, especially in the medial field, 
where $m$ is only a little shorter than the basal section of $M_{3}$ and $m$-cu has a different course, with the caudal end lying more distad than the cephalic portion.

\section{Hexatoma (Eriocera) trifasciata (Röder).}

Puerto Rico: El Yunque, Luquillo National Forest, June 7-10, 1935 (García Díaz). Las Mesas, near Mayagüez, over quiet pool in small stream, altitude 900 feet, November 3, 1935 (A. H. Madden).

Teucholabis (Teucholabis) myersi Alexander.

Cuba: Sierra Rangel, Pinar del Río, January 27-30, 1931 (Acuña \& Otero).

Teucholabis (Teucholabis) nigrosignata Alexander.

Cuba: Buenos Aires, Trinidad Mountains, altitude 2,350-2,800 feet, May 3, 1932 (Bruner \& Otero). Baracoa, Oriente, April 2130, 1929 (Bruner \& Leon Bouclé).

Teucholabis (Teucholabis) portoricana Alexander.

Puerto Rico: el Semille, Villalba, altitude 1,600 feet, at light, January 26, 1935 (Hoffman).

Teucholabis (Teucholabis) wighti sp. $\mathrm{n}$.

Size small (wing, ô, under $5 \mathrm{~mm}$.) ; general coloration yellow, the praescutum with three major polished black areas, pleura with a silvery longitudinal stripe; posterior tibiae of male with a narrow dilated ring at near three-fourths the length and a similar dilation near proximal end of posterior basitarsi ; wings whitish subhyaline, the stigma and a confluent seam of cord brown; $S c$ short; $R_{2}$ interstitial with fork of $R s$; branches of $R s$ strongly divergent; male hypopygium with apical spine of basistyle very small and weak; outer dististyle with a slender spine on mesal edge.

Male.-Length about $4.5 \mathrm{~mm}$; wing $4.8 \mathrm{~mm}$.

Rostrum and palpi yellow. Antennae with seape and pedicel obscure brownish yellow, flagellum black; flagellar segments oval, decreasing in size outwardly; segments with short apical necks. Head yellow.

Pronotum yellow. Mesonotal praescutum with the ground reddish brown, with three major black areas, involving the cephalic and lateral portions of the sclerite, the latter reaching the lateral margin; scutum with lobes extensively blackened, the broad median area obscure yellow; scutellum broad, yellow, parascutella darkened; mediotergite 
black, the central portion of anterior half a little paler. Pleura with the dorsal sclerites black, including the anepisternum, dorsal pteropleurite and pleurotergite; a conspicuous silvery longitudinal stripe extending from the fore coxae across the dorsal sternopleurite, ventral pteropleurite and meral region; ventral sternopleurite and dorsopleural membrane more yellowish. Halteres with stem darkened, knob light yellow. Leg's with coxae and trochanters yellow; femora yellow, with a narrow brown subterminal ring, the narrow apex a trifle narrower, the darkened ring subequal in width on all legs; tibiae obscure yellow, in male with a slightly enlarged brown ring at near three-fourths the length, this provided with a group of setae; tarsi yellow, the outer segments more darkened, in male with a slightly enlarged and darkened ring near proximal end of basitarsi. Wings (Fig. 8) whitish subhyaline, the stigma and a narrow confluent seam on cord dark brown; veins pale brown. Venation: Sc relatively short, $S c_{1}$ ending about opposite one-fifth the length of $R s$; $R_{2}$ interstitial with cord, at end of $R s$; anterior branch of $R s$ in direct alignment with the stem, the branches widely divergent so cell $R_{4}$ at margin is approximately twice as wide as cell $R_{2}$; cell 1 st $M_{2}$ closed, gently widened outwardly, shorter than vein $M_{1}+{ }_{2}$ beyond it; $m$-cu shortly beyond fork of $M$; vein $C u_{2}$ very short and pale, indicated only at base.

Abdominal tergites black, the incisures a little more reddish piceous; basal sternites yellow, transversely ringed at near midlength with dark brown; subterminal segments whitened; hypopygium abruptly black. Male hypopygium (Fig. 7) with the apical spine of basistyle, $b$, very short, weak and slender; dorsal flange long but only feebly sclerotized. Outer dististyle, od, with apical half a flattened blade, glabrous except on outer margin, constricted at its base and at this point on mesal edge produced into a slender spine. Crest of inner dististyle, id, high, the apex obtuse, the beak bidentate.

Habitat.-Jamaica.

Holotype, ô, Balaclava (A. E. Wight).

Teucholabis (Teucholabis) wights is named in honor of the collector, who has taken many of the Jamaican Tipulidae now preserved in the Museau of Comparative Zoölogy. It is most nearly allied to the Cuban $T$. (T.) nigrosignata Alexander, differing especially in the narrow subterminal femoral rings, the wing pattern and venation, and the structure of the male hypopygium, especially the small weak apical spine of basistyle and the spine on mesal edge of the outer dististyle. 
THE JOURNAL OF AGRICULTURE OF THE UNIVERSITY OF P. R.

Gonomyia (Idiocera) angustissima Alexander.

Cuba: Soledad, April 1926 (Bequaert). San Blas, Santa Clara, Trinidad Mountains, altitude 700 feet, December 4, 1931 (Rowe).

Gonomyia (Lipophleps) bifiligera Alexander.

Puerto Rico: El Semille, Villalba, altitude 1,600 feet, at light, January 26, 1935 (Hoffman).

Gonomyia (Lipophleps) sandersi Alexander.

Cuba: Laguna Castellanos, Wojay, Havana, February 14, 1931 (Otero). The specimen, a male, has cell $M_{2}$ of both wings open by the atrophy of basal section of $M_{2}$.

Gonomyia (Lipophleps) pleuralis (Williston).

Cuba: Santiago de las Vegas, March 3, 1931 (Otero); July 12, 1930 (Bruner).

Gonomyia (Lipophleps) monacantha platymera subsp.n.

Male.-Length about $3.5 \mathrm{~mm}$; wing $3.8 \mathrm{~mm}$.

Female.-Length about $5 \mathrm{~mm}$; wing $4.5 \mathrm{~mm}$.

Differs from the typical form in the structure of the male hypopygium (Fig. 18). Outer spine of outer dististyle, od, much stouter than in either monacanthia or helophila Alexander, the apex blackened and microscopically roughened by appressed spinulae, smooth in the others; basal spine of outer dististyle a strongly blackened flange that extends into a strong spine, the outer margin of flange more or less irregularly serrate, the surface slightly scabrous. Inner dististyle, $i d$, simple.

Habitat.-Cuba.

Holotype, $\hat{o}$, Soledad, near Cienfuegos, August 6-20 (Banks).

Allotype, + , San Blas, Santa Clara, August 12, 1932 (Bates \& Fairchild).

When more material becomes available, this fly will probably be accorded full specific ranking.

\section{Erioptera (Mesocyphona) costalis Alexander.}

Cuba: San Blas, Santa Clara, July 20-August 12, 1932 (Bates \& Fairchild). 
Erioptera (Trimicra) pitipes anomala (Osten Sacken).

Bermuda: Cavendish, January (W. S. Brooks). Swamp near Hamilton, December (W. S. Brooks).

Toxorhina (Toxorhina) domingensis Alexander.

Cuba: San Blas, Santa Clara, August 20, 1932 (Bates \& Fairchild). 


\section{EXPLANATION OF FIGURES}

(Symbols: Male hypopygium; $a$, aedeagus ; $b$; basistyle; $d$, dististyle; $g$, gonapophysis; $i d$, inner dististyle; od, outer dististyle; $s$, sternite; $t$, tergite; $v d$, ventral dististyle.)

Fig. 1.-Tanypremna (Tanypremna) hodgei sp.n., venation.

Fig. 2.-Dolichopeza (Megistomastix) domingensis sp. n., venation. Fig. 3.-Limonia (Limonia) domballah sp. n., venation.

Fig. 4.- Shannonomyia batesi sp.n., venation.

Fig. 5.- Shannonomyia haitensis sp. n., venation.

Fig. 6.-Shannonomyia septem-punctata sp. n., venation.

Fig. 7.-Hexatoma (Eriocera) ornaticornis sp. n., venation.

Fig. 8.-Teucholabis (Teucholabis) wighti sp. n., venation.

Fig. 9.-Rhabdomastix fumipennis sp. n., venation.

Fig. 10.-Tanypremna (Tanypremna) hodgei sp.n., male hypopygium|

Fig. 11.-Dolichopeza (Megistomastix) darlingtoni sp.n., male hypopygium.

Fig. 12.-Dolichopeza (Megistomastix) domingensis sp.n., male hypopygium.

Fig. 13.-Limonia (Limonia) apicata dominicensis subsp. n., male hypopygium.

Fig. 14.-Limonia (Geranomyia) banksiana sp. n., male hypopygium.

Fig. 15.-Limonia (Geranomyia) microphaea sp.n., male hypopygium.

Fig. 16.-Limonia (Geranomyia) sylvania sp.n., male hypopygium. Fig. 17.-Teucholabis (Teucholabis) wighti sp. n., male hypopygium. Fig. 18.-Gonomyia (Lipophleps) monacantha platymera subsp. n., male hypopygium. 
PLATE I
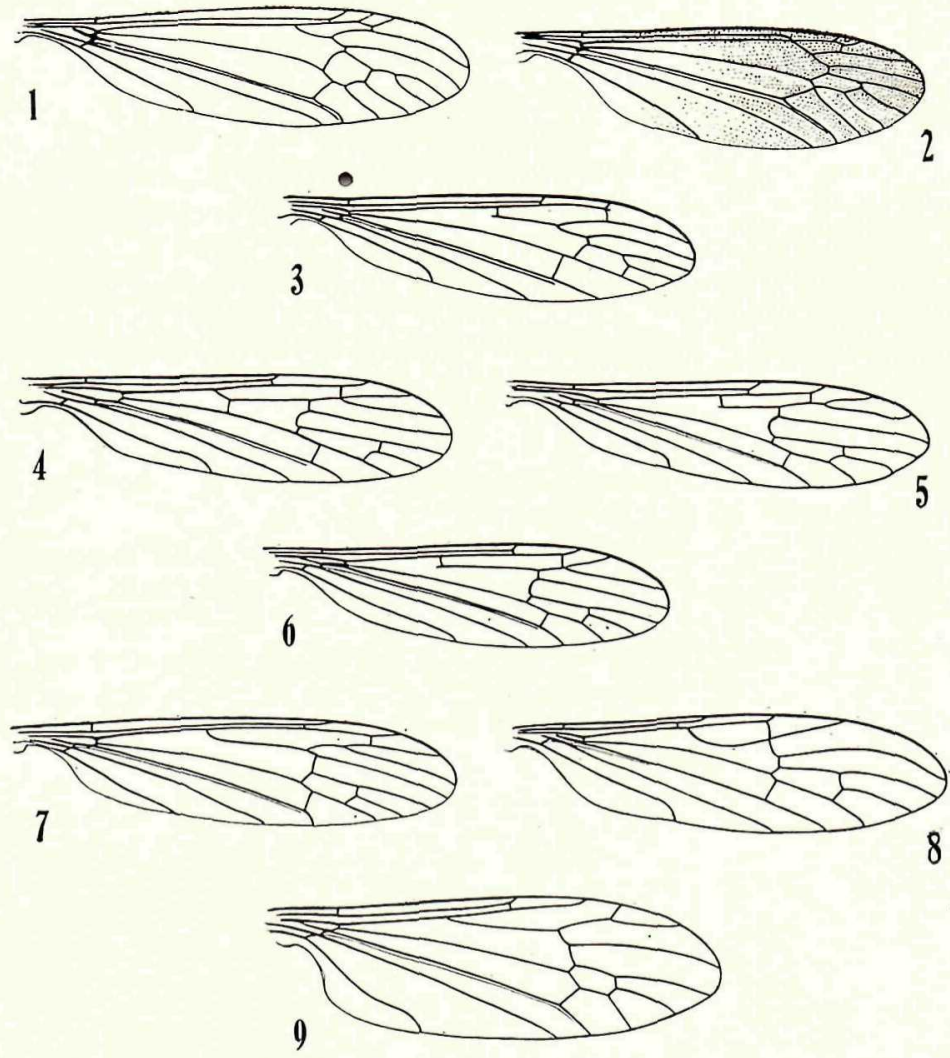

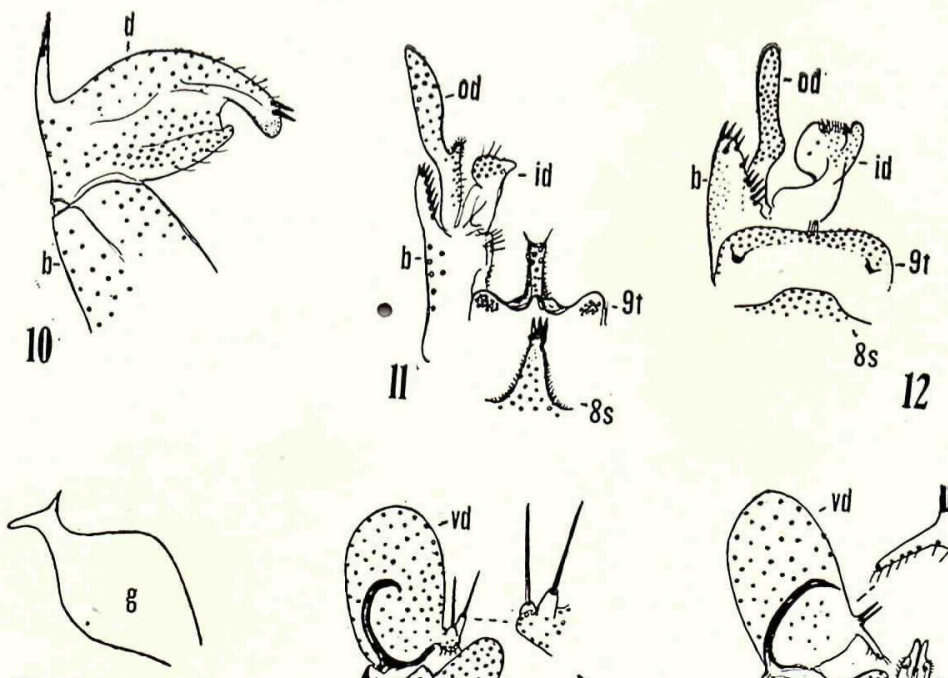

13
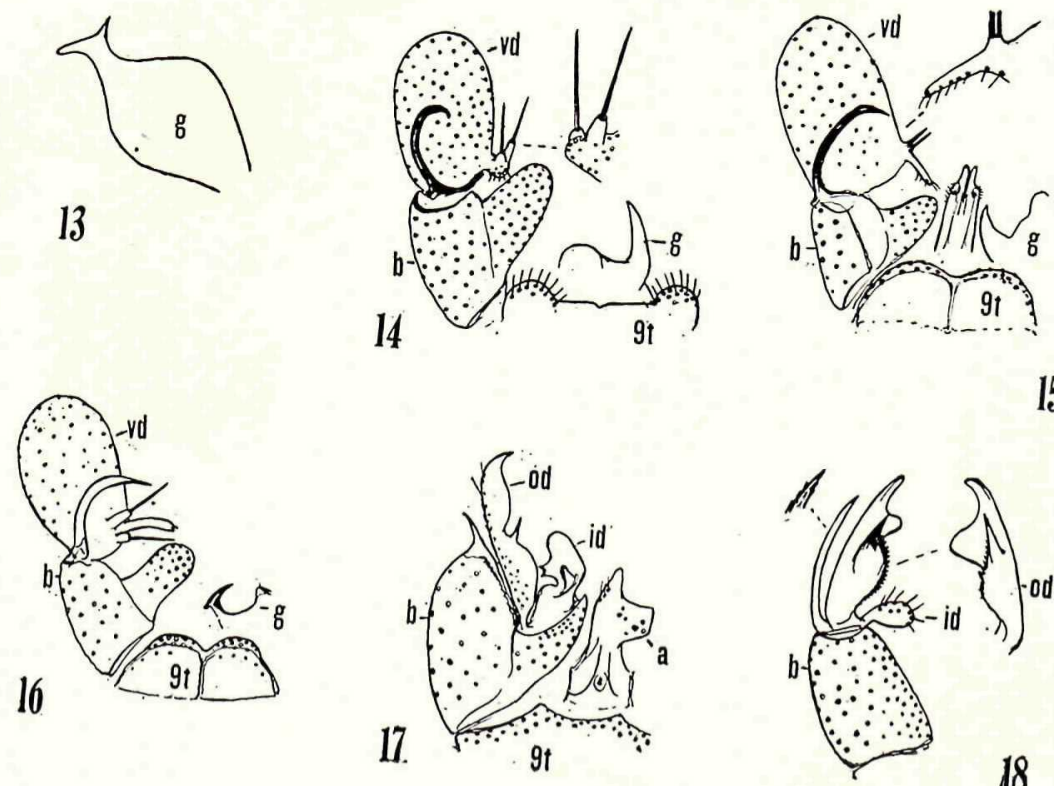

15

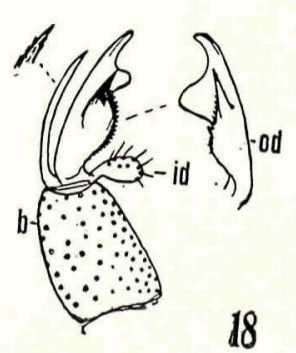

